\title{
EXPLORING THE SATISFACTION OF ECOTOURISM IN PROTECTED NATURAL AREAS
}

\author{
Mauricio CARVACHE-FRANCO* \\ Universidad Espíritu Santo-Ecuador, Km 2.5 Vía Samborondón, \\ Samborondón, Ecuador, e-mail: mauricio2714@hotmail.com \\ Orly CARVACHE-FRANCO \\ Universidad Católica de Santiago de Guayaquil, Facultad de Especialidades Empresariales, \\ Av. Carlos Julio Arosemena Km 1.5, Guayaquil, Ecuador, e-mail: orly.carvache@cu.ucsg.edu.ec \\ Wilmer CARVACHE-FRANCO \\ ESPOL Polytechnic University, Escuela Superior Politécnica del Litoral, ESPOL, \\ Faculty of Social Sciences and Humanities, Campus Gustavo Galindo Km 30.5 Vía Perimetral, \\ P.O. Box 09-01-5863, Guayaquil, Ecuador, e-mail: wcarvach@espol.edu.ec
}

Citation: Carvache-Franco, M., Carvache-Franco, O., \& Carvache-Franco, W. (2020). EXPLORING THE SATISFACTION OF ECOTOURISM IN PROTECTED NATURAL AREAS. GeoJournal of Tourism and Geosites, 29(2), 672-683. https://doi.org/10.30892/gtg.29223-498

\begin{abstract}
Enhancing the tourists' visit to protected areas is vital for destinations that have natural and cultural wealth. The objective of this study is to analyze the aspects of satisfaction with ecotourism in three important protected areas. The empirical study was conducted in situ at Morro Mangroves Wildlife Refuge, Santay Island National Recreation Area and Samanes National Recreation Area in Ecuador. Hence, with the use of quantitative correlational techniques, 382 questionnaires were analyzed. Findings reveal high satisfaction and loyalty in ecotourism. The most valued factors in the satisfaction were the tranquility, conservation of the natural and monumental heritage, the humane treatment received and the access to the infrastructure. In ecotourism, general satisfaction influences the intentions of returning, recommending and expressing positive things about the destination. These findings will contribute to the development of efficient marketing plans in destinations related to ecotourism.
\end{abstract}

Key words: Ecotourism, satisfaction, loyalty, demand, Ecuador

\section{INTRODUCTION}

Ecotourists, on average, show high satisfaction with their ecotourism experiences (Buckley, 2009; Butler \& Boyd, 2000; Lawton, 2001; Weaver, 2008). Also, managers increasingly realize the economic importance of meeting the needs of their visitors and providing them with memorable experiences (Fletcher \& Fletcher, 2003). In this sense, visitor satisfaction is a vital aspect of the marketing and management practices of national

\footnotetext{
* Corresponding author
}

http://gtg.webhost.uoradea.ro/ 
parks (Hwang et al., 2005; Ramkissoon et al., 2013). Most studies of protected areas evaluate some necessary attributes of the site, such as boats or trails, identifying a similar trend of high satisfaction (Fletcher \& Fletcher, 2003). Likewise, finding megafaunas and impressive ecosystems are key expressive attributes of satisfaction in protected areas (Curtin, 2003; Hvenegaard, 2002). Furthermore, understanding the concept/perception of satisfaction allows managers to provide facilities and services that match the expectations of visitors (Borrie \& Birzell, 2001; Tonge \& Moore, 2007). Similarly, understanding the expectations and satisfaction of visitors helps to plan the allocation of resources and provision of services (Bushell \& Griffin, 2006). It also allows visitors to obtain the natural and relaxation benefits they expect (Crilley et al., 2012). Therefore, the efficient management of visitor satisfaction is often a significant goal that park managers seek to achieve (Tonge \& Moore, 2007). Additionally, in tourism marketing, visitor satisfaction and behavioral intentions remain an essential area of research (Prayag et al., 2013). However, research in destinations related to nature and protected areas have been scarce in the scientific literature (Castellanos-Verdugo et al., 2016).

In this framework, the three protected areas are located in Guayas province in Ecuador, where ecotourism is a relevant modality due to the diversity of species of flora and fauna in the areas that belong to the National System of Protected Areas of Ecuador (SNAP). These were Morro Mangroves Wildlife Refuge, Santay Island National Recreation Area and Samanes National Recreation. This manuscript aims to analyze satisfaction in ecotourism and provide information to tourism marketers. Thus, it contributes to the planning of efficient marketing strategies. This paper is divided into six sections. The first section contains the introduction. The second section describes the literature. The third section displays the study area. The methodology appears in the fourth section. The fifth section shows the results. The manuscript ends with a sixth section with the discussion, conclusions, limitations and future lines of research.

\section{LITERATURE REVIEW}

Satisfaction is an emotional response derived from a consumer experience (Spreng et al., 1996). Similarly, satisfaction is as a post-consumer assessment that determines whether it meets or exceeds the expectations of tourists (Engel et al., 1993). Another definition for satisfaction is the cognitive-affective state derived from a consumer experience (Bosque \& Martin, 2008). Tourist satisfaction refers to the positive feeling or pleasure obtained after experiencing or consuming any tourist product (Beard \& Ragheb, 1980). Furthermore, satisfaction is a psychological aspect that derives from visiting an environment and an emotional state of mind after exposure to an opportunity (Howat \& Crilley 2007; Zabkar et al., 2010). In addition, the satisfaction of tourists who visit a national park or a protected area can be measured indirectly through the stimuli that tourists receive from that area. Moreover, satisfaction results from the experiences of visitors who are in contact with the natural characteristics and identity of a protected area (Chhetri et al., 2004; Bigné et al., 2005). Several researchers have recognized that satisfaction depends on the products, prices, quality of the services provided and the friendly attitude of the local inhabitants (Qu \& Li, 1997; Ryan, 1999; Stevens, 1992).

Some researchers have found that satisfaction is a general evaluation after purchase (Devesa et al., 2010; Sun et al., 2013; Yoon et al., 2010), which increases the likelihood that tourists will return to visit and recommend the destination to friends and family (Prayag \& Ryan, 2012). Futhermore, satisfaction comprises the choice of destination, the consumption of products and services, and the decision to return (Prayag \& Ryan, 2012; Žabkar et al., 2010). Hence, satisfaction is fundamental for tourism given the strong relationship between satisfaction and future customer behavior. This means that a satisfied consumer 
will repeat the visit and communicate the positive experiences to others (Emir \& Kozak, 2011). Therefore, satisfaction is conducive to repeat visits (Seetanah et al., 2020; Tonge et al., 2011; Zhang et al., 2018), achieve visitor loyalty (Abd Razaka et al., 2020; Chen \& Tsai, 2007), and promote frequent visits (Sivalıŏ̆lu \& Berköz, 2012).

Several studies reveal that satisfaction has a positive influence on post-purchase behavior (Abd Razaka et al., 2020; Cronin \& Taylor, 1992; Fornell, 1992; Keaveney, 1995). In addition, some studies have shown that repeated visits to a tourist destination are related to higher levels of visitor satisfaction because it motivates people to return to the same destination again (Carvache-Franco et al., 2019; Rittichainuwat et al., 2002; TianCole et al., 2002; Yuksel, 2001). In addition, other studies have found an impact between general satisfaction and satisfaction with different aspects with the intentions to return and recommend (Alegre \& Cladera, 2006; Carvache-Franco et al., 2020; Um et al., 2006). For Carvache-Franco et al. (2020), there is a significant and positive correlation between general satisfaction with the intentions to return and recommend an ecotourism destination. Regarding ecotourism satisfaction studies, the study by Tsiotsou \& Vasioti (2006) on tourism services in Greece identified several factors related to the satisfaction that include "staff satisfaction," "satisfaction with food," "satisfaction with the excursion," "satisfaction with socialization," and "satisfaction with the landscape," Furthermore, Meng et al. (2008) in their study on the satisfaction of nature-based tourist complexes in Virginia, identified some satisfaction factors, among them: friendly service/quality, outdoor activities, accommodation and natural landscapes.

In addition, Lee (2015) found the following satisfaction factors: information services, recreational facilities, and safety and sustainability. Similarly, Dolnicar et al. (2015) mentions that it is necessary to identify which attributes or factors of the service are more important and should improve to increase satisfaction and which attributes are not as important or have little influence on customer satisfaction. On the other hand, Adam et al. (2019) investigated the satisfaction and motivation of ecotourists visiting the Kakum National Park, and found the following factors: "educational satisfaction," "social satisfaction," "satisfaction with sanitation," and "satisfaction with relaxation". Morevoer, representative examples in ecotourism include a high satisfaction rate of $66 \%$ in the Pirongia Forest Park of New Zealand (Pan \& Ryan, 2007) and a 60\% satisfaction level in the Amboseli National Park of Kenya (Okello et al., 2008). For Abd Razaka et al. (2020) understanding the factors of tourist satisfaction leads to long-term relationships with customers and positively contributes to business growth.

\section{STUDY AREA}

In this section, the authors describe the protected areas with ecotourism potential: Morro Mangroves Wildlife Refuge, Santay Island National Recreation Area and Samanes National Recreation Area. These sites are located in Ecuador.

\section{Santay Island National Recreation}

It is located on the Guayas River, between the cities of Guayaquil and Duran in the Guayas Province. This protected area has international recognition as a wetland.

It is a Ramsar site since 2000. This declaration has made this site of global interest and a priority for nature conservation. Waterfalls visit this wetland for resting, sheltering and nesting. Moreover, the area houses 6o plant species, 12 reptile varieties and 128 types of birds, of which 12 are listed. This site is also notorious for its mangroves and, some trees protect unique mammals. Flora and fauna are the main ecotourism attractions, and tourists admire mangrove marine birds. Another attraction of the island is the Ecovillage, where visitors can observe crocodiles and observe the typical homes of the community of this site (Figure 1). 


\section{Exploring the Satisfaction of Ecotourism in Protected Natural Areas}
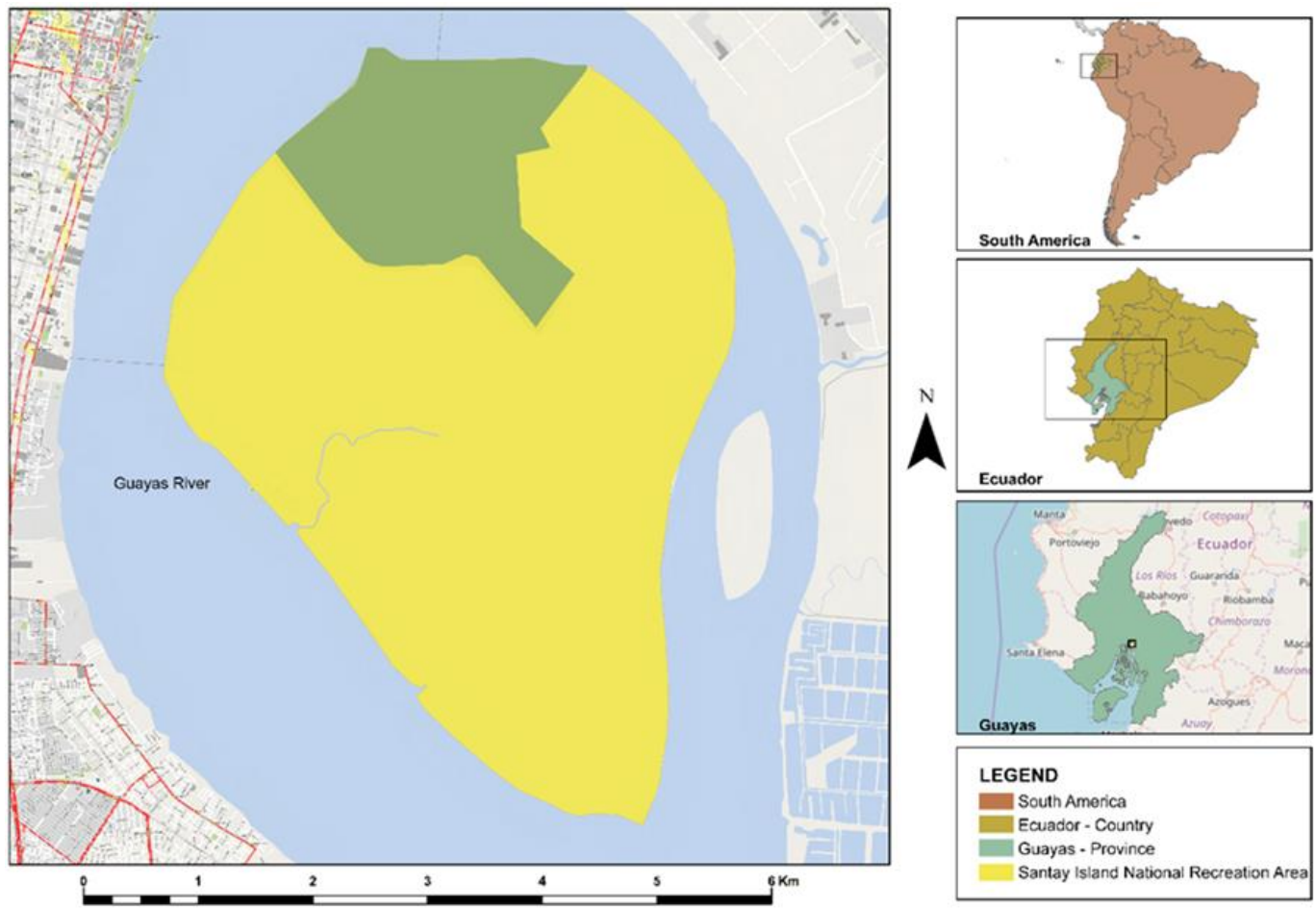

Figure 1. Geographical location of the Santay Island National Recreation


\section{LEGEND}

South America

Ecuador - Country

Guayas - Province

Santay Island National Recreation Area

Figure 2. Geographical location of the Morro Mangroves Wildlife Refuge 

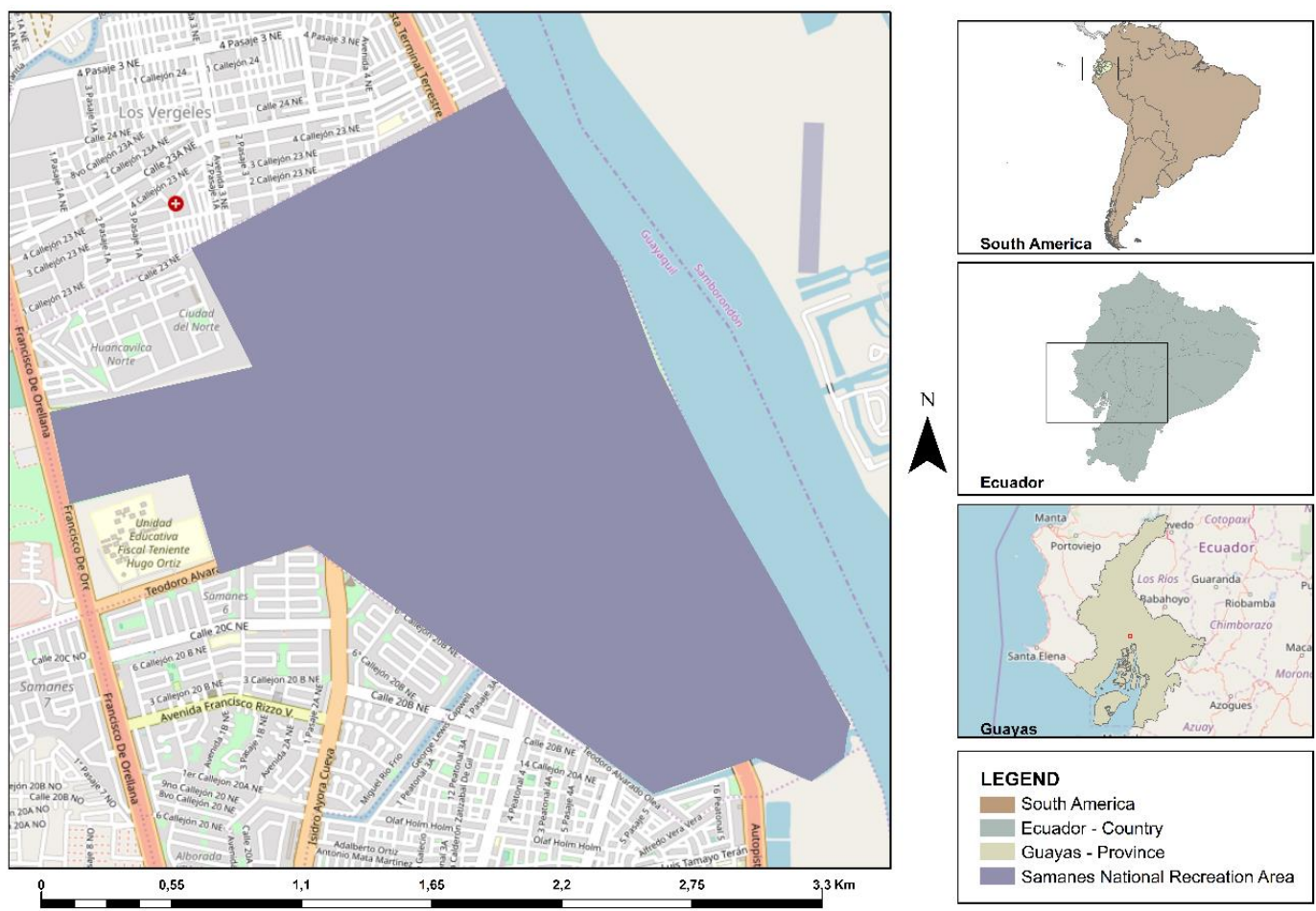

Figure 3. Geographical location of the Samanes National Recreation Area

\section{Morro Mangroves Wildlife Refuge}

It is located in the north of the Gulf of Guayaquil in Ecuador. A large population of dolphins inhabits the Morro Canal, and a frigate colony occupies Manglecito Island. The frigate colony contains approximately 6,000 individuals, which makes this site one of the highest concentrations of these birds in the world. There are four types of mangroves on this site: red, white, black and button. On its mainland, the refuge protects a small parcel of dry forest. More than 80 species live on this site, and seabirds are the most abundant in the refuge. Among the main attractions, visitors can observe dolphins, frigates, pelicans, bluefooted boobies, pink spoonbills, white ibis and cormorants. There are also shelters and nesting sites for frigates, pelicans and blue-footed boobies on Manglecito Island (Figure 2).

\section{Samanes National Recreation Area}

It is located in the north of Guayaquil, Ecuador. Remains of dry coastal forest and alluvial plains, which preserve the characteristics of the Guayas river basin, endure this area. The coastal dry forest is particularly frequent in the highest areas, where tourists can see trees such as Kapok, Vytex cymosa, Bototillo, Guasmo and even Guayacan, as well as the tree that gives the area its name, the Rain tree. The Samanes National Recreation Area is also home to many species of waterfowl such as cormorants, whistling ducks, coots and herons. On this site, visitors can enjoy several sports and leisure facilities (Figure 3).

\section{METHODOLOGY}

The questionnaire used in this study was adapted from previous studies on ecotourism satisfaction (Adam et al., 2019; Devesa et al., 2010; Lee, 2015; Meng et al., 2008; Tsiotsou \& Vasioti, 2006). The instrument contained two sections. In the first section, the researchers collected sociodemographic information. The second section 
dealt with the satisfaction and intentions of returning, recommending and making positive commentaries about the destination. Several types of questions, such as closed and five-point Likert scale were used to obtain reliable results. The satisfaction scale contained 13 items with a Likert scale of five points, corresponding to the different aspects of the destination. The Cronbach Alpha coefficient for the final scale resulted in a robust value of 0.89 (close to 1). Surveys were conducted in situ during January and July 2018 in the three protected areas. The authors trained the interviewers who completed the surveys when the tourists did recreational or leisure activities. The tourists surveyed were Ecuadorian adults and foreigners visiting one of the protected areas studied. The visitors completed the surveys while they rested after their ecotourism activities. The surveys were anonymous, and the interviewers assisted the visitors whenever they had questions. The interviewers collected a total of 382 valid questionnaires, and the infinite population was used. The researchers considered the sample performed the study with a margin of error of $+/-5 \%$, a confidence level of $95 \%$ and variability of $50 \%$. The Spearman correlation coefficient was used to know the significant relationships between the different variables. The statistical data was collected, organized, tabulated and analyzed through the SPSS program, version 22.

\section{RESULTS}

The sample consisted of $90.8 \%$ national tourists and $9.2 \%$ foreign tourists. Of the study population, $42.7 \%$ were men and $57.3 \%$ were women. $61.3 \%$ were in the age group between 20 and 29 years old, and $19.4 \%$ were in the group of 30 to 39 years old. The vast majority of tourists had university education at $77.0 \%$. From the tourists who visited the protected areas, $49 \%$ did so in the company of their family and $35.1 \%$ with friends. The visitors mostly arrived in groups of 3 to 5 people $(58.1 \%)$, followed by those who arrived with less than three people (26.70\%).

\section{General satisfaction and loyalty}

General satisfaction and loyalty was measured with a 5 point Likert scale (one means little, and five means a lot), the general satisfaction of the experience of visiting the destination in ecotourism had an average of 4.22. The response suggests the high potential of the resources in these three protected areas. Regarding aspects of future behavior, the intention to return to the destination obtained an average of 4.3 , and the intention to recommend the protected area obtained an average of 4.34. The variable "when I speak of these protected areas I mention positive things" obtained an average from 4.33 . Hence, findings show the high loyalty of visitors and the potential of ecotourism as a modality.

Table 1. Satisfaction and loyalty

\begin{tabular}{|l|c|c|c|c|}
\hline \multicolumn{1}{|c|}{ Variable } & N & Min. & Max. & Mean \\
\hline \multicolumn{1}{|c|}{ Latisfaction } & & & & \\
\hline Genaralty & 382 & $\mathbf{1}$ & 5 & 4.22 \\
\hline I intend to return to these protected areas & & & & \\
\hline I have the intention to recommend these protected areas & 382 & $\mathbf{1}$ & 5 & 4.30 \\
\hline $\begin{array}{l}\text { When I talk about these protected areas, I will give } \\
\text { positive comments }\end{array}$ & 382 & $\mathbf{2}$ & 5 & 4.34 \\
\hline
\end{tabular}

Relationship among general satisfaction and the intentions to return, recommend and say positive things

Through a Spearman correlation, the relationship among general satisfaction with intentions to return, recommend and say positive things about the ecotourism destiny has been analyzed. As shown in Table 2, overall satisfaction presented a significant and 
positive correlation with the intentions of returning, recommending and saying positive things about the destination. Therefore, by improving the level of general satisfaction of tourists, the intentions to return, recommend and say positive things about the ecotourism destination will increase. Hence, to increase the level of general satisfaction of tourists, there must be an analysis of the relationship between general satisfaction with satisfaction in the different aspects of the service. In addition, the aspects of the service that have the most significant influence on the overall satisfaction should be known.

Table 2. General satisfaction with the intentions to return, recommend and say positive things

\begin{tabular}{|l|c|}
\hline \multicolumn{1}{|c|}{ Variable } & Correlation \\
\hline I intend to return to these protected areas & $0.552^{* *}$ \\
\hline I have the intention to recommend these protected areas & $0.606^{* * *}$ \\
\hline When I talk about these protected areas, I will give positive comments & $0.579^{* *}$ \\
\hline
\end{tabular}

${ }^{* *}$ Significance $1 \%$

\section{The satisfaction with the appearance of the site}

The satisfaction in protected areas was measured with a 5 point Likert scale (one means little and five means a lot). Findings reveal that the most valued aspects were: tranquility with an average of 4.19 , followed by conservation of the natural heritage and monumental with 4.09, the human treatment received with 4.04 and access to infrastructure with 3.96. These results indicate that the natural and cultural resources of the destination are well-preserved. Moreover, there is vast tranquility forecreation in natural areas, and there is adequate access to infrastructure (Table 3)

Tables 3. The satisfaction with the appearance of the site

\begin{tabular}{|l|c|c|c|c|c|}
\hline \multicolumn{1}{|c|}{ Variable } & N & Min. & Max. & Mean & Stand. Dev. \\
\hline Calmness & 382 & 1 & 5 & 4.19 & 0.886 \\
\hline Conservation of natural and cultural heritage & 382 & 1 & 5 & 4.09 & 0.893 \\
\hline How locals treat tourists & 382 & 1 & 5 & 4.04 & 0.928 \\
\hline Accessibility and infrastructure & 382 & 1 & 5 & 3.96 & 1.013 \\
\hline Traffic signs & 382 & 1 & 5 & 3.92 & 1.049 \\
\hline Parking & 382 & 1 & 5 & 3.92 & 1.031 \\
\hline Prices & 382 & 1 & 5 & 3.89 & 0.991 \\
\hline Tourist information and signs & 382 & 1 & 5 & 3.87 & 1.013 \\
\hline Sport facilities & 382 & 1 & 5 & 3.85 & 1.159 \\
\hline Gastronomy & 382 & 1 & 5 & 3.79 & 1.029 \\
\hline Restaurant facilities/equipment & 382 & 1 & 5 & 3.74 & 1.013 \\
\hline Complimentary leisure activities (festivals, shows) & 382 & 1 & 5 & 3.41 & 1.264 \\
\hline Guided tours & 382 & 1 & 5 & 3.21 & 1.725 \\
\hline
\end{tabular}

Relationship of different aspects of satisfaction with general satisfaction

The relationship between the different aspects of satisfaction and general satisfaction was analyzed with the Spearman correlation coefficient. The results are shown in Table 4. According to Table 4, all the satisfaction aspect variables presented a significant and positive correlation with the overall satisfaction.

Therefore, the variables that had a more significant influence on the overall satisfaction are the equipment and facilities of the restaurants, gastronomic quality, prices and local's behavior with tourists. These were the service variables that should be improved to increase the level of overall satisfaction in this destination.

\section{destination}

Relationship of satisfaction by aspect with the intention to return to the 
Table 4. Different aspects of satisfaction related to general satisfaction

\begin{tabular}{|l|c|}
\hline \multicolumn{1}{|c|}{ Variable } & Correlation \\
\hline Restaurant facilities/equipment & $0.464^{* *}$ \\
\hline Gastronomy & $0.439^{* *}$ \\
\hline Prices & $0.431^{* *}$ \\
\hline How locals treat tourists & $0.410^{* *}$ \\
\hline Parking & $0.401^{* * *}$ \\
\hline Accessibility and infrastructure & $0.400^{* *}$ \\
\hline Tourist information and signs & $0.397^{* * *}$ \\
\hline Conservation of natural and cultural heritage & $0.395^{* *}$ \\
\hline Calmness & $0.378^{* * *}$ \\
\hline Sport facilities & $0.367^{* *}$ \\
\hline Traffic signs & $0.361^{* *}$ \\
\hline Complimentary leisure activities (festivals, shows) & $0.35^{* * *}$ \\
\hline Guided tours & $0.351^{* *}$ \\
\hline
\end{tabular}

**Significance $1 \%$

The relationship of satisfaction by aspect with the intention of returning to the destination was analyzed with the Spearman correlation coefficient. The results are shown in Table 5 .

Table 5. Satisfaction by aspect with intentions to return to the destination

\begin{tabular}{|l|c|}
\hline \multicolumn{1}{|c|}{ Variable } & Correlation \\
\hline Accessibility and infrastructure & $0.432^{* *}$ \\
\hline Prices & $0.429^{* *}$ \\
\hline Parking & $0.418^{* * *}$ \\
\hline Traffic signs & $0.401^{* *}$ \\
\hline Conservation of natural and cultural heritage & $0.384^{* *}$ \\
\hline Calmness & $0.368^{* *}$ \\
\hline Restaurant facilities/equipment & $0.360^{* *}$ \\
\hline Sport facilities & $0.349^{* *}$ \\
\hline How locals treat tourists & $0.341^{* *}$ \\
\hline Gastronomy & $0.340^{* *}$ \\
\hline Tourist information and signs & $0.338^{* *}$ \\
\hline Guided tours & $0.236^{* *}$ \\
\hline Complimentary leisure activities (festivals, shows) & $0.296^{* *}$ \\
\hline${ }^{* *}$ Significance 1\% &
\end{tabular}

According to Table 5, all the satisfaction aspect variables, except for guided visits, presented a significant and positive correlation with the intentions of returning to the destination. Thus, the variables that had more considerable influence on the intentions of returning to the destination were: access to infrastructure, prices, parking, and signaling on roads. These were the service variables that could be improved to increase the level of intention to return to this destination.

\section{the destination}

Relationship of satisfaction by aspects and the intentions to recommend

The relationship of satisfaction by aspect and the intention of recommending the destination was analyzed with the Spearman correlation coefficient. The results are shown in Table 6. According to Table 6, all the satisfaction aspect variables present a significant and positive correlation with the intention of recommending a destination. In this sense, the variables that had a more significant influence on the intentions of recommending the destination were: Prices, parking, human treatment received and 
access to infrastructure. The findings show that these were the service variables that should be improved to increase the level of intentions to recommend the destination.

Table 6. Satisfaction by aspect and the intention to recommend the destination

\begin{tabular}{|l|c|}
\hline \multicolumn{1}{|c|}{ Variable } & Correlation \\
\hline Prices & $0.445^{* *}$ \\
\hline Parking & $0.430^{* * *}$ \\
\hline How locals treat tourists & $0.424^{* *}$ \\
\hline Accessibility and infrastructure & $0.423^{* *}$ \\
\hline Calmness & $0.421^{* *}$ \\
\hline Traffic signs & $0.415^{* *}$ \\
\hline Conservation of natural and cultural heritage & $0.385^{* *}$ \\
\hline Restaurant facilities/equipment & $0.381^{* *}$ \\
\hline Tourist information and signs & $0.378^{* *}$ \\
\hline Gastronomy & $0.361^{* *}$ \\
\hline Complimentary leisure activities (festivals, shows) & $0.325^{* *}$ \\
\hline Guided tours & $0.317^{* *}$ \\
\hline Sport facilities & $0.286^{* * *}$ \\
\hline **Significance 1\% & \\
\hline
\end{tabular}

\section{DISCUSSION AND CONCLUSIONS}

The findings show that overall satisfaction was high, along with the intention to return, recommend and say positive things. The most valued factors in the satisfaction by aspect were tranquility, conservation of the natural and monumental patrimony, the humane treatment received and access to the infrastructure. Therefore, in ecotourism, general satisfaction influences the intention of returning to the destination, similar results were found in other studies (Abd Razaka et al., 2020; Carvache-Franco et al., 2020; Seetanah et al., 2020; Zhang et al., 2018). Moreover, satisfaction influences the intentions of recommending a destination. Similar findings were presented in other studies (Carvache-Franco et al., 2020; Prayag \& Ryan, 2012). Additionally, satisfaction influences the intention of saying positive things about the destination. Analogous results were identified in studies (Carvache-Franco et al., 2020; Emir \& Kozak, 2011).

Furthermore, all the variables of satisfaction by appearance influenced general satisfaction. Also, all the variables of satisfaction by aspect influenced the intention of returning to the destination and the intention of recommending the destination. Similar results were observed in other studies (Alegre \& Cladera, 2006; Carvache-Franco et al., 2020; Um et al., 2006). In ecotourism, general satisfaction is more influenced by the equipment and facilities of the restaurants, gastronomic quality, prices and the humane treatment received. While the intention to return to the destination is affected by access to infrastructure, prices, parking and signaling on roads. On the other hand, the intention of recommending the destination is more influenced by prices, parking, the humane treatment received and the access to the infrastructure. Therefore, to improve the service, it is necessary to increase the level of general satisfaction of tourists.

Thus, the intention to return and recommend a destination increases. Above all, improving prices, access to infrastructure, and treatment received will increase overall satisfaction and future visits to ecotourism destinations. Among the practical implications, companies related to ecotourism should plan strategies to improve the level of satisfaction in the different aspects of the service. In this way, they should be able to improve the level of general satisfaction of tourists, increase future visits of tourists, and enhance the recommendation of the destination. Thus, the companies contribute to the development of the destination and the community. Finally, the main 
limitation of the present study was the temporality of the information gathering because the demand can vary depending on the tourist season. A future line of research is the relationship between satisfaction and demand segments.

\section{REFERENCES}

Abd Razaka, A., Shamsudinb, M. F., \& Abdul, R. M. (2020). The Influence of Atmospheric Experience on Theme Park Tourist's Satisfaction and Loyalty in Malaysia. https://www.ijicc.net/images/Vol6Iss9/6904_ Razak_2019_E_R.pdf.

Adam, I., Adongo, C. A., \& Amuquandoh, F. E. (2019). A structural decompositional analysis of eco-visitors' motivations, satisfaction and post-purchase behaviour. Journal of Ecotourism, 18(1), 60-81. https://doi.org/10.1080/14724049.2017.1380657.

Alegre, J., \& Cladera, M. (2006). Repeat visitation in mature sun and sand holiday destinations. Journal of Travel Research, 44(3), 288-297. https://doi.org/10.1177/0047287505279005.

Anderson, E. W., \& Sullivan, M. W. (1990). Customer satisfaction and retention across firms. In TIMS College of Marketing Special Interest Conference on Services Marketing, Nashville, TN, September.

Baker, D. A., \& Crompton, J. L. (2000). Quality, satisfaction and behavioral intentions. Annals of Tourism Research, 27(3), 785-804. https://doi.org/10.1016/So160-7383(99)00108-5.

Baker, D. A., \& Crompton, J. L. (2000). Quality, satisfaction and behavioral intentions. Annals of Tourism Research, 27(3), 785-804. https://doi.org/10.1016/S0160-7383(99)00108-5.

Beard, J. G., \& Ragheb, M. G. (1980). Measuring leisure satisfaction. Journal of Leisure Research, 12(1), $20-33$. https://doi.org/10.1080/00222216.1980.11969416.

Bigné, J. E., Andreu, L., \& Gnoth, J. (2005). The theme park experience: An analysis of pleasure, arousal and satisfaction. Tourism Management, 26(6), 833-844. https://doi.org/10.1016/j.tourman.2004.05.006

Blamey, R. K. (2001). Principles of ecotourism. The Encyclopedia of Ecotourism, 2001, 5-22.

Borrie, W. T., \& Birzell, R. M. (2001). Approaches to measuring quality of the wilderness experience. In: Freimund, Wayne A.; Cole, David N., comps. Visitor use density and wilderness experience: proceedings; 2000 June 13; Missoula, MT. Proceedings RMRS-P-20. Ogden, UT: US Department of Agriculture, Forest Service, Rocky Mountain Research Station. p. 29-38., 20, 29-38.

Buckley, R. (2009). Ecotourism: Principles and practices. CABI.

Bushell, R., \& Griffin, T. (2006). Monitoring visitor experiences in protected areas. Protected Areas Programme, 25.

Butler, R., \& Boyd, S. W. (2000). Tourism and national parks. Chichester: Wiley

Caneen, J. M. (2003). Cultural determinants of tourist intention to return. Tourism Analysis, 8(2), $237-242$. https://doi.org/10.3727/108354203774076805.

Carvache-Franco, M., Carvache-Franco, O., Carvache-Franco, W., \& Villagómez-Buele, C. (2020). From Satisfaction in Eco-Tourism To Loyalty in a National Park. GeoJournal of Tourism and Geosites, 28 (1), 191-202. https://doi.org/10.30892/gtg.28115-462.

Carvache-Franco, M., Víquez-Paniagua, A. G., Carvache-Franco, O., Perez-Orozco, A., \& Carvache-Franco, W. (2019). Motivations, Intentions to Return and to Recommend Protected Areas: A Study In Costa Rica. GeoJournal of Tourism and Geosites, 27 (4), 1173-1183. https://doi.org/10.30892/gtg.27405-424.

Castellanos-Verdugo, M., Vega-Vázquez, M., Oviedo-García, M. Á., \& Orgaz-Agüera, F. (2016). The relevance of psychological factors in the ecotourist experience satisfaction through ecotourist site perceived value. Journal of Cleaner Production, 124, 226-235. https://doi.org/10.1016/j.jclepro.2016.02.126.

Chen, C., \& Tsai, D. (2007). How destination image and evaluative factors affect behavioral intentions? Tourism Management, 28(4), 1115-1122. https://doi.org/10.1016/j.tourman.2006.07.007.

Chhetri, P., Arrowsmith, C., \& Jackson, M. (2004). Determining hiking experiences in nature-based tourist destinations. Tourism management, 25(1), 31-43. https://doi.org/10.1016/So261-5177(03)ooo57-8.

Chi, C.G., Qu, H., 2008. Examining structural relationship of destination image, tourist satisfaction and destination loyalty: an integrated approach. Tourism Management. 29(4), 624-636. http://dx.doi.org/ 10.1016/j.tourman.2007.06.007.

Crilley, G., Weber, D., \& Taplin, R. (2012). Predicting visitor satisfaction in parks: Comparing the value of personal benefit attainment and service levels in Kakadu National Park, Australia. Visitor Studies, 15(2), 217-237. https://doi.org/10.1080/10645578.2012.715038.

Crompton, J. L., \& Love, L. L. (1995). The predictive validity of alternative approaches to evaluating quality of a festival. Journal of Travel Research, 34(1), 11-24. https://doi.org/10.1177/004728759503400102.

Cronin Jr, J. J., \& Taylor, S. A. (1992). Measuring service quality: a reexamination and extension. Journal of Marketing, 56(3), 55-68. https://doi.org/10.1177/002224299205600304.

Curtin, S. (2003). Whale-watching in Kaikoura: Sustainable destination development? Journal of Ecotourism, 2(3), 173- 195. https://doi.org/10.1080/14724040308668143. 
del Bosque, I. R. \& San Martín, H. (2008). Tourist satisfaction a cognitive-affective model. Annals of Tourism Research, 35(2), 551-573. https://doi.org/10.1016/j.annals.2008.02.006.

Devesa, M., Laguna, M. \& Palacios, A. (2010). The role of motivation in visitor satisfaction: Empirical evidence in rural tourism. Tourism Management, 31(4), 547-552. http://dx.doi.org/10.1016/j.tourman.2009.06.006.

Dharmaratne, G. S., Sang, F. Y., \& Walling, L. J. (2000). Tourism potentials for financing protected areas. Annals of Tourism Research, 27(3), 590-610. https://doi.org/10.1016/So160-7383(99)00109-7.

Dolnicar, S., Coltman, T., \& Sharma, R. (2015). Do satisfied tourists really intend to come back? Three concerns with empirical studies of the link between satisfaction and behavioral intention. Journal of Travel Research, 54(2), 152-178. https://doi:10.1177/0047287513513167.

Engel, J., Blackwell, R., \& Miniard, P. (1993). FL: Dryden Press. Consumer behavior. Orlando.

Fletcher, D., \& Fletcher, H. (2003). Manageable Predictors of Park Visitor Satisfaction: Maintenance and Personnel. Journal of Park \& Recreation Administration, 21(1).

Fornell, C. (1992). A national customer satisfaction barometer: the Swedish experience. Journal of Marketing, 56(1), 6-21. https://doi.org/10.1177/002224299205600103.

Geva, A., \& Goldman, A. (1991). Satisfaction measurement in guided tours. Annals of Tourism Research, 18(2), 177-185. https://doi.org/10.1016/0160-7383(91)90002-S.

Hornback, K. E., \& Eagles, P. F. (1999). Guidelines for public use measurement and reporting at parks and protected areas. IUCN.

Howat, G., \& Crilley, G. (2007). Customer service quality, satisfaction, and operational performance: A proposed model for Australian public aquatic centres. Annals of Leisure Research,10(2), $168-195$. https://doi.org/10.1080/11745398.2007.9686760.

Hvenegaard, G. T. (2002). Using tourist typologies for ecotourism research. Journal of Ecotourism, 1(1), 7-18. https://doi.org/10.1080/14724040208668109.

Hwang, S. N., Lee, C., \& Chen, H. J. (2005). The relationship among tourists' involvement, place attachment and interpretation satisfaction in Taiwan's national parks. Tourism Management, 26(2) $143-156$. https://doi.org/10.1016/j.tourman.2003.11.006.

Keaveney, S. M. (1995). Customer switching behavior in service industries: An exploratory study. Journal of Marketing, 59(2), 71-82. https://doi.org/10.1177/002224299505900206

Kozak, M. (2001). Repeaters' behavior at two distinct destinations. Annals of Tourism Research, 28(3), 784807. https://doi.org/10.1016/So160-7383(00)00078-5.

Kozak, M., \& Rimmington, M. (2000). Tourist satisfaction with Mallorca, Spain, as an off-season holiday destination. Journal of Travel Research, 38(3), 260-269. https://doi.org/10.1177/004728750003800308.

Lawton, L. J. (2001). Public protected areas. The encyclopedia of ecotourism, 287-302.

Lee, C. F. (2015). Tourist satisfaction with forest recreation experience: a segment-based approach. Anatolia, 26(4), 535-548. https://doi.org/10.1080/13032917.2014.997768.

Lounsbury, J. W., \& Hoopes, L. L. (1985). An investigation of factors associated with vacation satisfaction. Journal of Leisure Research, 17(1), 1-13. https://doi.org/10.1080/o0222216.1985.11969610.

Meng, F., Tepanon, Y., \& Uysal, M. (2008). Measuring tourist satisfaction by attribute and motivation: The case of a nature-based resort. Journal of Vacation Marketing, 14(1), 41-56. https://doi.org/10.1177/ 1356766707084218 .

Okello, M. M., D'Amour, D. E., \& Manka, S. G. (2008). Tourism attractions and satisfaction of Amboseli National Park, Kenya. Tourism Analysis, 13(4), 373-386.

Oliver, R. L. (1980). A cognitive model of the antecedents and consequences of satisfaction decisions. Journal of Marketing Research, 17(4), 460-469. https://doi.org/10.1177/002224378001700405.

Oliver, R. L., \& Swan, J. E. (1989). Consumer perceptions of interpersonal equity and satisfaction in transactions: a field survey approach. Journal of Marketing, 53(2), 21-35. https://doi.org/10.1177/ 002224298905300202.

Pan, S., \& Ryan, C. (2007). Mountain areas and visitor usage - motivations and determinants of satisfaction: The case of Pirongia Forest Park, New Zealand. Journal of Sustainable Tourism, 15(3), $288-308$. https://doi.org/10.2167/jost662.o.

Petrick, J. F. (2004). Are loyal visitors desired visitors?. Tourism Management, 25(4), $463-470$. https://doi.org/10.1016/So261-5177(03)o0116-X.

Prayag, G., \& Ryan, C. (2012). Antecedents of tourists' loyalty to Mauritius: The role and influence of destination image, place attachment, personal involvement, and satisfaction. Journal of Travel Research, 51(3), 342-356. https://doi.org/10.1177/0047287511410321.

Prayag, G., Hosany, S., \& Odeh, K. (2013). The role of tourists' emotional experiences and satisfaction in understanding behavioral intentions. Journal of Destination Marketing \& Management, 2(2), 118-127. http://dx.doi.org/10.1016/j.jdmm.2013.05.001.

Pritchard, M. P. (2003). The attitudinal and behavioral consequences of destination performance. Tourism analysis, 8(1), 61-73. https://doi.org/10.3727/108354203108750175.

Qu, H., \& Li, I. (1997). The characteristics and satisfaction of mainland Chinese visitors to Hong Kong. Journal of Travel Research, 35(4), 37-41. https://doi.org/10.1177/004728759703500406. 
Ramkissoon, H., Smith, L. D. G., \& Weiler, B. (2013). Testing the dimensionality of place attachment and its relationships with place satisfaction and pro-environmental behaviours: A structural equation modelling approach. Tourism Management, 36, 552-566. https://doi.org/10.1016/j.tourman.2012.09.003.

Rittichainuwat, B. N., Qu, H., \& Mongknonvanit, C. (2002). A study of the impactof travel satisfaction on the likelihood of travelers to revisit Thailand. Journal of Travel \& Tourism Marketing, 12(2-3), 19-43. https://doi.org/10.1300/Jo73v12no2_03.

Ross, G. F. (1993). Destination evaluation and vacation preferences. Annals of Tourism Research, 20(3), 477489. https://doi.org/10.1016/0160-7383(93)90004-M

Ryan, C. (1999). From the psychometrics of SERVQUAL to sex: Measurements of tourist satisfaction. Consumer behavior in travel and tourism, 267-286.

Sampol, C. J. (1996). Estimating the probability of return visits using a survey of tourist expenditure in the Balearic Islands. Tourism Economics, 2(4), 339-351. https://doi.org/10.1177/135481669600200404

Seetanah, B., Teeroovengadum, V., \& Nunkoo, R. (2020). Destination satisfaction and revisit intention of tourists: does the quality of airport services matter?. Jou.rnal of Hospitality \& Tourism Research, 44(1), 134-148. https://doi.org/10.1177/1096348018798446

Sivalığlu, P., \& Berköz, L. (2012). Perceptual evaluation of the national park users. Procedia - Social and Behavioral Sciences, 50(o), 928-940. https://doi.org/10.1016/j.sbspro.2012.08.094

Spreng, R., Mackenzie, S., \& Olshavsky, R. (1996). A re-examination of the determinants of consumer satisfaction. Journal of Marketing, 6o(3), 15-32. https://doi.org/10.1177/002224299606000302

Stevens, B.F., 1992. Price value perceptions of travellers. Journal of Travel Research, 31 (2), 44-48. https://doi.org/10.1177/004728759203100208

Sun, X., Chi, C. G. Q., \& Xu, H. (2013). Developing destination loyalty: The case of Hainan Island. Annals of Tourism Research, 43, 547-577. http://dx.doi.org/10.1016/j.annals.2013.04.006

Tian-Cole, S., Crompton, J. L., \& Willson, V. L. (2002). An empirical investigation of the relationships between service quality, satisfaction and behavioral intentions among visitors to a wildlife refuge. Journal of Leisure Research, 34(1), 1-24. https://doi.org/10.1080/00222216.2002.11949957

Tonge, J., \& Moore, S. A. (2007). Importance-satisfaction analysis for marine-park hinterlands: A Western Australian case study. Tourism Management, 28(3), 768-776. https://doi.org/10.1016/j.tourman.2006.05.007.

Tonge, J., Moore, S. A., \& Taplin, R. (2011). Visitor satisfaction analysis as a tool for park managers: A review and case study. Annals of Leisure Research, 14(4), 289-303. https://doi.org/10.1080/11745398.2011.639339.

Tsiotsou, R., \& Vasioti, E. (2006). Using demographics and leisure activities to predict satisfaction with tourism services in Greece. Journal of Hospitality \& Leisure Marketing, 14(2), 69-82. https://doi.org/10.1300/J150v14no2_05.

Um, S., Chon, K., \& Ro, Y. (2006). Antecedents of revisit intention. Annals of Tourism Research, 33(4), 11411158. https://doi.org/10.1016/j.annals.2006.06.003.

Weaver, D. (2008). Ecotourism (2nd ed.). Milton: Wiley.

Yoon, Y. S., Lee, J. S., \& Lee, C. K. (2010). Measuring festival quality and value affecting visitors' satisfaction and loyalty using a structural approach. International Journal of Hospitality Management, 29(2), 335-342. http://dx.doi.org/10.1016/j.ijhm.2009.10.002

Yoon, Y., \& Uysal, M. (2005). An examination of the effects of motivation and satisfaction on destination loyalty: a structural model. Tourism Management, 26(1), 45-56. https://doi.org/10.1016/j.tourman.2003.08.016.

Yuksel, A., 2001. Managing customer satisfaction and retention: a case of tourist destinations, Turkey. Journal of Vacation Marketing, 7 (2), 153-168. https://doi.org/10.1177/135676670100700205.

Žabkar, V., Brenčič, M. M., \& Dmitrović, T. (2010). Modelling perceived quality, visitor satisfaction and behavioural intentions at the destination level. Tourism Management, 31(4), 537-546. https://doi.org/10.1016/j.tourman.2009.06.005.

Zhang, H., Wu, Y., \& Buhalis, D. (2018). A model of perceived image, memorable tourism experiences and revisit intention. Journal of Destination Marketing \& Management, 8, 326-336. https://doi.org/10.1016/j. jdmm.2017.06.004.

Submitted:

06.02.2020
Revised:

27.04.2020
Accepted and published online 04.05.2020 